\title{
Papers
}

\section{Tacrolimus versus ciclosporin as primary immunosuppression for kidney transplant recipients: meta-analysis and meta-regression of randomised trial data}

\author{
Angela C Webster, Rebecca C Woodroffe, Rod S Taylor, Jeremy R Chapman, Jonathan C Craig
}

\begin{abstract}
Objective To compare the positive and negative effects of tacrolimus and ciclosporin as initial treatment for renal transplant recipients.

Design Systematic review.

Data sources and study selection Reports of comparative randomised trials of tacrolimus and ciclosporin identified by searches of Medline, Embase, the Cochrane Register of Controlled Trials, the Cochrane Renal Group Specialist Register, and conference proceedings.

Data extraction and synthesis Two reviewers assessed trials for eligibility and quality and extracted data independently. Data were synthesised (random effects model) and results expressed as relative risk (RR), with values $<1$ favouring tacrolimus. Subgroup analysis and meta-regression were used to examine potential effect modification by differences in trial design and immunosuppressive co-interventions.
\end{abstract}

Results 123 reports from 30 trials (4102 patients) were included. At six months, graft loss was significantly reduced in tacrolimus treated recipients $(\mathrm{RR}=0.56,95 \%$ confidence interval 0.36 to 0.86 ), and this effect persisted up to three years. The relative reduction in graft loss with tacrolimus diminished with higher concentrations of tacrolimus $(\mathrm{P}=0.04)$ but did not vary with ciclosporin formulation $(\mathrm{P}=0.97)$ or ciclosporin concentration $(\mathrm{P}=0.38)$. At one year, tacrolimus treated patients had less acute rejection $(\mathrm{RR}=0.69,0.60$ to 0.79$)$ and less steroid resistant rejection ( $\mathrm{RR}=0.49,0.37$ to 0.64 ) but more diabetes mellitus requiring insulin $(\mathrm{RR}=1.86,1.11$ to 3.09$)$, tremor, headache, diarrhoea, dyspepsia, and vomiting. The relative excess of diabetes increased with higher concentrations of tacrolimus $(\mathrm{P}=0.003)$. Ciclosporin treated recipients had significantly more constipation and cosmetic side effects. No differences were seen in infection or malignancy.

Conclusions Treating 100 recipients with tacrolimus instead of ciclosporin for the first year after transplantation avoids 12 patients having acute rejection and two losing their graft but causes an extra five patients to develop insulin dependent diabetes. Optimal drug choice may vary between patients.

\section{Introduction}

Renal transplantation is the treatment of choice for most patients with end stage renal disease. The introduction of ciclosporin in the early 1980s improved one year graft survival from $60 \%$ to more than $80 \% .^{12}$ Tacrolimus emerged as an alternative calcineurin inhibitor during the early 1990 s. $^{3}$ Pronounced global differences in use of tacrolimus exist; $63 \%$ of new renal transplant recipients in the United States receive tacrolimus for primary immunosuppression compared with only $22 \%$ in Australia. $^{12}$

Despite the impact of calcineurin inhibitors on initial outcome, longer term graft survival is little changed. ${ }^{14}$ Major causes of loss are chronic allograft nephropathy and death (most commonly cardiovascular) with a functioning graft. ${ }^{5}$ Proved atherogenic risk factors in the general population (diabetes mellitus, dyslipidaemia, and hypertension) are more common in the renal transplant population. ${ }^{6}$ To what degree recipient mortality and graft loss can be attributed to these risk factors, to the direct toxicity of immunosuppression, or to cumulative effects of infection and rejection is debated. ${ }^{7}$ What is known is that tacrolimus and ciclosporin affect these risk factors differentially. Tacrolimus is associated more with diabetes and neurotoxicity but less with hypertension and dyslipidaemia than is ciclosporin, with uncertainty about equivalence of nephrotoxicity or how these relate to patient and graft survival or affect patients' compliance and quality of life..$^{6-8}$

The objective of this study was to systematically review randomised controlled trials in which tacrolimus had been compared with ciclosporin as initial immunosuppressive therapy in the treatment of kidney transplant recipients.

\section{Methods}

\section{Inclusion criteria}

We included all randomised trials comparing tacrolimus with ciclosporin solution (Sandimmun) or ciclosporin microemulsion (Neoral) as initial immunosuppressive therapy, with any combination of additional immunosuppressive treatments in the intervention and control arms. We excluded trials in which participants received another solid organ in addition to a kidney transplant (such as kidney with pancreas).

\section{Literature search}

We comprehensively searched Medline (1966-October 2003), Embase (1980-October 2003), Cochrane Collaboration resources, and conference proceedings. Two reviewers (AW and RW or RT) independently screened combined search results.

Where we suspected duplicate reporting of the same patient group, we contacted authors for clarification. If duplication was confirmed, the first complete publication was the primary data source, and only this is referenced here. Full details of this process and a list of all reports identified, grouped by trial, are available in the extended Cochrane version of this review. 


\section{Outcome measures}

Primary outcomes analysed were graft loss (censored for death), acute rejection, and steroid resistant rejection. Additional outcomes sought were death, graft loss including death with functioning allograft, graft function, malignancy, infectious complications, chronic allograft nephropathy, incidence of diabetes mellitus, and side effects of treatment. Two reviewers (AW and RW or RT) independently extracted data, using a standardised form.

\section{Methodological quality of trials}

Two reviewers (AW and RW or RT) assessed trials independently. Quality items examined were concealment of allocation, blinding, intention to treat analysis, and completeness of followup.

\section{Quantitative data synthesis and data analysis}

We extracted data and then used Review Manager 4.2.3 (Cochrane Collaboration) to pool them for summary estimates. We expressed results for dichotomous outcomes as relative risk, with values of $<1$ favouring tacrolimus, and continuous outcomes as weighted mean difference, both with $95 \%$ confidence intervals.

We analysed heterogeneity among trials by using a Cochran $Q$ test and calculating $I^{2}$ to measure the proportion of total variation due to heterogeneity beyond chance. ${ }^{9}$ We did the analyses with both random and fixed effects models and found no important differences. Results reported here used the random effects model, as this is more conservative in the presence of heterogeneity. ${ }^{10}$

We did subgroup analyses and meta-regression for the primary outcomes and for the most commonly reported complication, diabetes mellitus, to explore important clinical differences among trials that might be expected to alter the magnitude of treatment effect. Subgroups defined a priori were publication type, methodological quality of trial, and baseline immunological risk of the trial population. Additionally, we assessed publication bias by using funnel plots of the log odds ratio. ${ }^{11}$

Meta-regression variables included ciclosporin formulation (solution or microemulsion), level of exposure to both tacrolimus and ciclosporin (calculated by using the midpoint of each trial's declared intention to treat target ranges at the 12 hour post-dose nadir, averaged over the first year post-transplantation), the specific combination of additional baseline immunosuppressive agents, and the dose of steroids used. We used Stata software to do meta-regression on the log relative risk scale, with each trial weighting equal to the inverse of the variance of the estimate for that study and between study variance estimated with the restricted maximum likelihood method.

\section{Results}

\section{Literature search}

We included 123 reports of 30 trials (fig 1) - a total of 4102 randomised participants. ${ }^{12-41}$ Five of these trials were available in abstract form only (239 participants), and the remaining 25 (3863 participants) were reported in 18 different journals. Most of the reports were in English; two reports were in French, and one was in German.

\section{Included trials}

Six trials (1127 participants) compared tacrolimus with the oil based solution formulation of ciclosporin (Sandimmun), and 19 trials (2744 participants) compared tacrolimus with the

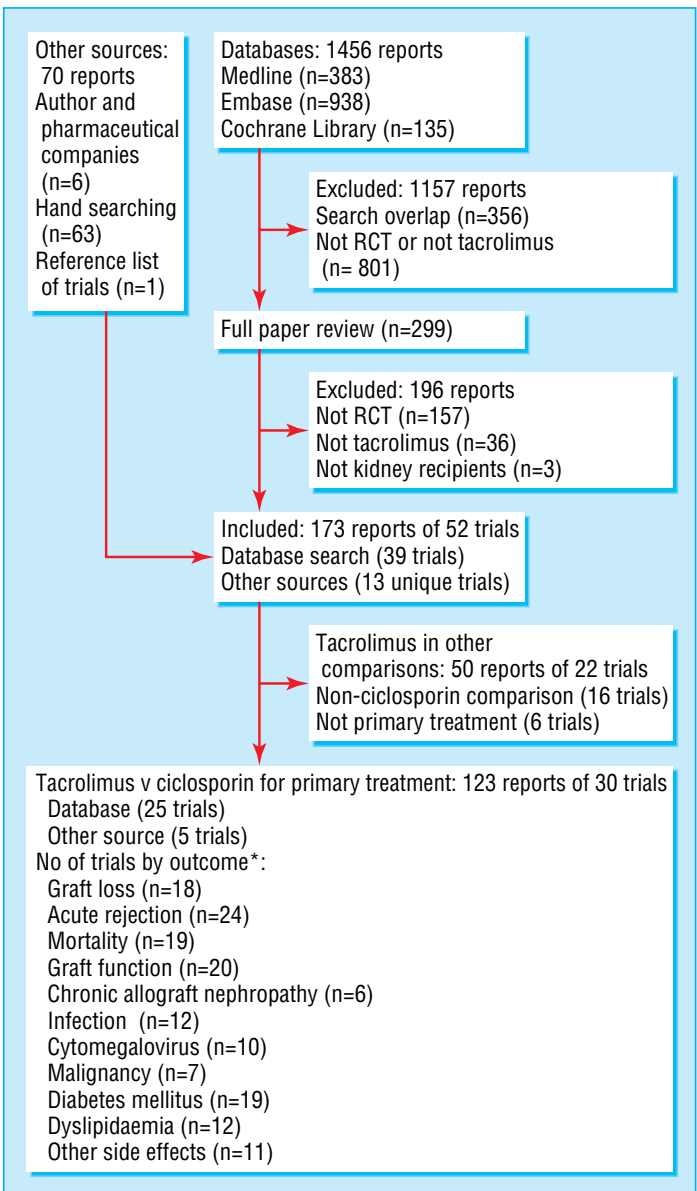

Fig 1 Flowchart showing process of identification of randomised controlled trials for inclusion in systematic review. RCT=randomised controlled trial. *Not all trials reported outcomes with sufficient detail to allow data to contribute to meta-analysis

microemulsion formulation (Neoral). We were unable to clarify which formulation was used for the remaining five trials (231 participants) (table 1).

Most trials were restricted to participants with low baseline risk for transplantation. Only two trials included participants with panel reactive antibodies $>50 \%,{ }^{21}{ }^{25}$ and nine trials included a proportion (range 10-25\%) of participants who had a previously failed renal transplant. ${ }^{15} 2425272930343639$ A further trial was conducted exclusively in children, ${ }^{34}$ and another included only African-Americans ${ }^{31}$; both of these populations are widely perceived to be at greater risk of rejection and complications. ${ }^{42}{ }^{43}$ Additional baseline immunosuppression varied. Three trials varied the antiproliferative agent across three trial arms, investigating combinations of tacrolimus and ciclosporin with mycophenolate or azathioprine. ${ }^{142138}$ Azathioprine was used in both tacrolimus and ciclosporin arms in 16 trials and mycophenolate in eight trials. One trial used sirolimus,${ }^{26}$ one used mirzoribine,${ }^{20}$ and one used no antiproliferative agent ${ }^{39}$; one trial did not state which was used. ${ }^{32}$ Seventeen trials reported their corticosteroid regimen in detail; the remaining 13 trials noted only that "local protocol" or "a standard reducing schedule" was followed. 121315 17-20 222332333538

Transplant focused outcomes were reported far more frequently (for example, acute rejection in 24 trials) than were complications of immunosuppression (for example, cytomegalovirus infection in nine trials) (fig 1). For many adverse events the 
Table 1 Characteristics of trials included in review

\begin{tabular}{|c|c|c|c|c|c|c|c|c|c|c|c|c|}
\hline \multirow{3}{*}{$\begin{array}{l}\text { Trials* (stratified by } \\
\text { formulation of } \\
\text { ciclosporin } \\
\text { comparator) }\end{array}$} & \multirow[b]{3}{*}{ No } & \multirow[b]{3}{*}{$\begin{array}{l}\text { Cadaveric } \\
\text { donor }(\%)\end{array}$} & \multirow{3}{*}{$\begin{array}{c}\text { First } \\
\text { transplant } \\
(\%)\end{array}$} & \multicolumn{3}{|c|}{ Tacrolimus } & \multicolumn{3}{|c|}{ Ciclosporin } & \multicolumn{2}{|c|}{ Co-interventions $\dagger$} & \multirow{3}{*}{$\begin{array}{l}\text { Length of } \\
\text { follow-up } \\
\text { (years) }\end{array}$} \\
\hline & & & & & $\begin{array}{r}\text { Conce } \\
\text { (n }\end{array}$ & $\begin{array}{l}\text { ation } \\
\text { nl) }\end{array}$ & \multirow[b]{2}{*}{$\begin{array}{l}\text { Initial dose } \\
(\mathrm{mg} / \mathrm{kg} / \mathrm{d})\end{array}$} & \multicolumn{2}{|c|}{ Concentration ( $\mathrm{ng} / \mathrm{ml}$ ) } & \multirow{2}{*}{$\begin{array}{c}\text { Antiproliferative } \\
\text { agent: Aza } \\
(\mathrm{mg} / \mathrm{kg} / \mathrm{d}), \text { MMF } \\
(\mathrm{g} / \mathrm{d})\end{array}$} & \multirow[b]{2}{*}{ Other } & \\
\hline & & & & $\begin{array}{c}\text { Initial dose } \\
\text { (mg/kg/d) }\end{array}$ & Initial & $\begin{array}{l}\text { Three } \\
\text { month }\end{array}$ & & Initial & $\begin{array}{l}\text { Three } \\
\text { month }\end{array}$ & & & \\
\hline \multicolumn{13}{|c|}{ Solution (Sandimmun) } \\
\hline Ichimaru $2001^{20}$ & 32 & NS & NS & NS & $10-15$ & $10-15$ & NS & $150-200$ & $150-200$ & MMF (NS) & Mizoribine & 0.5 \\
\hline Laskow $1995^{22}$ & 130 & 100 & 100 & $0.2-0.4$ & $5-40$ & $5-40$ & $6-14$ & NS & NS & Aza (1-1.5) & ALG & 1 \\
\hline Mayer $1997^{25}$ & 448 & 100 & 90 & 0.3 & $10-20$ & $5-15$ & 8 & $100-300$ & $100-150$ & Aza (1-2) & & 5 \\
\hline Pirsch $1997^{29}$ & 412 & 100 & 87 & 0.2 & $10-25$ & $5-15$ & 10 & $150-400$ & $100-300$ & Aza (1.5) & ATG/OKT3 & 5 \\
\hline Radermacher $1998^{30}$ & 48 & NS & 75 & $0.2-0.3$ & $10-20$ & $5-15$ & $5-8$ & 150 & $100-150$ & Aza (1.1) & & 1 \\
\hline Shapiro $1991^{32}$ & 57 & 100 & 100 & 0.3 & NS & NS & 4 IV & NS & NS & NS & & 1 \\
\hline \multicolumn{13}{|c|}{ Microemulsion (Neoral) } \\
\hline Agha $2001^{12} \ddagger$ & 28 & 68 & NS & NS & NS & NS & NS & NS & NS & Aza (NS) & ATG & 0.2 \\
\hline Busque $2001^{14}$ & 67 & 100 & 100 & NS & 8-16 & $5-15$ & NS & $200-400$ & $100-300$ & $\begin{array}{c}\text { Aza (1.5-2), MMF } \\
\text { (2) }\end{array}$ & & 0.5 \\
\hline Campos $2002^{15}$ & 166 & 49 & 95 & 0.2 & $15-20$ & 10-15 & 10 & $300-400$ & $200-400$ & Aza (1.5-2) & & 1 \\
\hline Charpentier $2002^{16}$ & 555 & NS & NS & 0.3 & $10-20$ & $5-15$ & 8 & $150-300$ & $100-200$ & Aza (1-2) & ATG & 0.5 \\
\hline Egfjord $2002^{17} \ddagger$ & 60 & NS & NS & NS & NS & NS & NS & NS & NS & MMF (NS) & ATG & 3.5 \\
\hline El Haggan $2002^{18}$ & 44 & 100 & NS & NS & NS & $5-10$ & NS & NS & $150-200$ & MMF (2) & ATG & 1 \\
\hline Johnson $2000^{21}$ & 223 & 100 & 100 & $0.15-0.2$ & 8-16 & $5-15$ & $8-10$ & $200-400$ & $100-300$ & $\begin{array}{c}\text { Aza (1.5-2), MMF } \\
\text { (2) }\end{array}$ & ATG/0KT3 & 3 \\
\hline Margreiter $2002^{24}$ & 560 & 96 & 93 & 0.3 & $10-20$ & $5-15$ & 8-10 & $100-400$ & $100-200$ & Aza (1-2) & & 3 \\
\hline Miller $2002^{26}$ & 150 & 100 & 100 & 0.2 & 10 & 6-8 & 10 & $200-250$ & $175-225$ & $\begin{array}{c}\text { MMF (2) } \\
\text { Sirolimus (8) }\end{array}$ & Daclizumab & 1 \\
\hline Morris-Stiff $1998^{27}$ & 179 & 100 & 83 & 0.2 & 5-15 & $5-15$ & 8 & $100-200$ & $100-200$ & Aza (1.5) & & 3 \\
\hline Nichelle $2002^{28}$ & 94 & NS & NS & 0.2 & $5-10$ & $5-10$ & 6 & $100-150$ & $100-150$ & Aza (1) & & 3 \\
\hline$\overline{\text { Raofi } 1999^{31}}$ & 35 & 100 & 100 & NS & $10-15$ & $10-15$ & NS & $150-200$ & $150-200$ & Cy:Aza (2) T: nil & OKT3 & 1 \\
\hline Toz $2001^{33} \ddagger$ & 17 & 65 & NS & $0.1-0.2$ & $8-11$ & NS & $5-7$ & $250-320$ & NS & Aza (NS) & & 0.25 \\
\hline Trompeter $2002^{34}$ & 204 & 16 & 88 & 0.3 & $10-20$ & $5-10$ & 150 & $150-200$ & $100-200$ & Aza (2) & & 0.5 \\
\hline Tsinalis $2000^{35} \ddagger$ & 53 & NS & NS & NS & NS & NS & NS & NS & NS & $\begin{array}{c}\text { T:Aza (NS), Cy: } \\
\text { MMF (NS) }\end{array}$ & & 0.5 \\
\hline Wang $2000^{37}$ & 57 & 100 & NS & $0.15-0.3$ & $10-20$ & $5-10$ & $6-8$ & $250-400$ & $150-300$ & MMF (2) & & 1 \\
\hline White $2000^{39}$ & 102 & $79 \S$ & 88 & $0.1-0.2$ & 8-15 & $5-10$ & $7-15$ & $200-300$ & $100-200$ & None & & 1 \\
\hline Yang $1999^{40}$ & 60 & 62 & 100 & 0.16 & $15-20$ & $10-20$ & 8 & $300-400$ & $200-300$ & MMF (1) & OKT3 & 1 \\
\hline Yu $2000^{41}$ & 90 & 100 & NS & $0.15-0.3$ & $10-20$ & $10-20$ & 8 & NS & $200-400$ & $\begin{array}{c}\text { Aza (NS), MMF } \\
\text { (1) }\end{array}$ & & 0.5 \\
\hline \multicolumn{13}{|l|}{ Unknown } \\
\hline Baskin $2002^{13} \ddagger$ & 81 & Ns & NS & $0.1-0.3$ & $10-25$ & $10-25$ & 5-7 & $150-200$ & $150-250$ & $\begin{array}{c}\text { Aza }(1.5), M M F \\
(2)\end{array}$ & & 0.5 \\
\hline Heering $1998^{19}$ & 16 & Ns & NS & $10-20$ & $10-20$ & $5-10$ & 10 & $100-300$ & $100-150$ & Aza (2) & & 0.5 \\
\hline Liu $2003^{23}$ & 27 & 100 & NS & $0.1-0.2$ & $6-8$ & 6-8 & $5-7$ & $220-300$ & $220-300$ & MMF (1.5-2) & ALG & 0.5 \\
\hline $\begin{array}{l}\text { Van Duijnhoven } \\
2002^{36}\end{array}$ & 23 & 100 & 78 & 0.3 & $10-15$ & $7-10$ & 8 & $100-200$ & $100-150$ & Aza (2) & & 0.5 \\
\hline Weimer $2002^{38}$ & 84 & 75 & $<100$ & NS & NS & NS & NS & NS & NS & $\begin{array}{c}\text { Aza (NS), MMF } \\
\text { (NS) }\end{array}$ & ATG & 0.25 \\
\hline
\end{tabular}

IV=intravenous; NS=not stated.

${ }^{*}$ Trials named by first author and year of first full publication. Data reported may be derived from this publication or from additional reports of the same trial

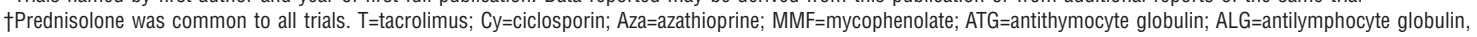

OKT3=monomunab-CD3.

fTrials reported only in abstract form.

$\S$ Includes $40 \%$ non-heart beating donors.

measures reported varied widely. Eleven $(36 \%)$ trials reported hypercholesterolaemia: three reported the number of participants with high cholesterol, and the remaining eight reported the summary average of total cholesterol. Of these eight, two did not report the standard deviation of these estimates, so data could not be combined. The remaining six trials reported at five different time intervals after transplantation, ranging from one month to three years, making meaningful meta-analysis difficult. Similar inconsistencies applied to reporting of graft function and hypertension.

\section{Quality of included trials}

Reporting of methods was incomplete for most trials. Four trials reported adequate allocation concealment, ${ }^{22} 243439$ two used inadequate methods, ${ }^{31}{ }^{36}$ and the remaining 24 trials were randomised but gave no indication of the method used. No trials were blinded. Intention to treat analysis was confirmed for 12 trials, ${ }^{16} 1921$ 25-27 29-31 374041 not done for eight trials, ${ }^{15} 18222428323436$ and unclear for 10 trials. Completeness of follow-up was neither reported nor deducible for 10 trials $^{12-14} 17232831323638$; it ranged between $77 \%$ and $100 \%$ for the remainder.

\section{Outcomes}

Transplant focused outcomes

All primary outcomes favoured the use of tacrolimus over ciclosporin. Graft loss censored for death was reduced in tacrolimus treated recipients at all time points and reached statistical significance at six months (graft loss reduced by $44 \%$; relative risk $=0.56,95 \%$ confidence interval 0.36 to 0.86 ) and at three years $(29 \% ; 0.71,0.52$ to 0.96$)$ after transplantation (fig 2). Significantly fewer tacrolimus treated patients had acute 
rejection, whether diagnosed clinically or confirmed by biopsy, beyond thee months after transplantation (table 2). The effect of tacrolimus in steroid resistant rejection was even more marked, with $55 \%$ reduction at six months (relative risk $=0.45,0.33$ to $0.60)$ (fig 3).

The only consistently reported measure of graft function across trials was mean serum creatinine. At six months, tacrolimus treated patients had a significantly lower mean creatinine: $0.14 \mathrm{mg} / \mathrm{dl}(12.25 \mu \mathrm{mol} / \mathrm{l})$ less than in ciclosporin treated patients (eight trials, $95 \%$ confidence interval -0.27 to -0.01 $\mathrm{mg} / \mathrm{dl}$ ), although significant heterogeneity of trial results existed $\left(\mathrm{P}=0.04, I^{2}=52 \%\right)$ (table 2). Subgrouping trials by clarity of reporting showed that the heterogeneity was limited to the three trials in which the number of participants who contributed creatinine measurements was clearly stated (heterogeneity: $\mathrm{P}=0.17$, $I^{2}=42 \%$ ), but the source of the variability was unexplained. These trials also showed a larger mean reduction in creatinine with tacrolimus $(-0.47 \mathrm{mg} / \mathrm{dl}(-41.63 \mu \mathrm{mol} / \mathrm{l}),-0.81$ to -0.13 $\mathrm{mg} / \mathrm{dl})$. In the remaining five trials, the exact number of participants measured was not directly reported but had to be calculated or inferred from other data; the summary result showed less difference in mean creatinine measurements between treatment groups and across trials (creatinine -0.05 $\mathrm{mg} / \mathrm{dl}(-4.40 \mu \mathrm{mol} / \mathrm{l}),-0.13$ to $0.03 \mathrm{mg} / \mathrm{dl}$; heterogeneity: $\left.\mathrm{P}=0.89, I^{2}=0 \%\right)$.

\section{Complications and side effects of immunosuppression}

A limited number of trials reported the incidence of infection or malignancy. We found no differences in effect for these outcomes (table 3).

The most consistent definition used to report disturbance of glucose metabolism was "new diabetes mellitus," defined as a requirement for insulin treatment for $\geq 30$ days in previously non-diabetic patients. The risk of new diabetes at six months, one year, and three years was significantly increased in tacrolimus treated recipients (relative risks $2.56,1.37$ to $4.78 ; 1.86,1.11$ to $3.09 ; 3.86,2.01$ to 7.41$)$. The results at one year showed significant heterogeneity $\left(\mathrm{P}=0.01, I^{2}=54.3 \%\right)$, largely owing to one trial that reported very different rates of new diabetes-9.0\% in the tacrolimus arms compared with $12.9 \%$ in the other trials and $20 \%$ in the ciclosporin arm compared with $5.5 \%$ in the other trials. ${ }^{26}$ Although this difference is not explicable by differences in methods or trial population, this was the only trial to use sirolimus as a co-intervention (fig 4). Sensitivity analysis showed a relative risk of 2.19 (1.42 to 3.38) and much reduced heterogeneity $\left(\mathrm{P}=0.18, I^{2}=27.5 \%\right)$ when this trial was removed from the analysis.

Tacrolimus treated patients were significantly more likely than ciclosporin treated patients to have tremor, headache, dyspepsia, vomiting, diarrhoea, and hypomagnesaemia. Ciclosporin patients were significantly more likely to have constipation, hirsutism, and gingival hyperplasia (table 3).

\section{Subgroup analysis and meta-regression}

Subgroup analysis on the basis of publication type, methodological quality of the trial, and baseline immunological risk of the trial population showed no evidence of any difference in the summary estimates for graft loss. However, we found a significant difference $(\mathrm{P}=0.01)$ for acute rejection dependent on publication status. Trials published only in non-peer reviewed journals or abstract form showed no difference between tacrolimus and ciclosporin (three trials; relative risk 1.02, 0.57 to 1.82), whereas those published in peer reviewed journals showed a significant reduction in acute rejection ( 11 trials; $0.64,0.57$ to 0.72 ) (table 4 ).
We were unable to determine whether this difference reflected publication bias, other reporting bias, or true heterogeneity, as the funnel plot (not shown) was uninformative and details of methods were absent for some trials.

When we compared trials conducted exclusively in adult recipients of primary cadaveric transplants (low immunological risk) with those containing a proportion of recipients of subsequent transplants, children, or African-Americans (mixed and high immunological risk), we found no evidence of any difference between risk groups (table 4).

Notably, meta-regression showed that higher tacrolimus concentrations were associated with an increased risk of graft loss compared with lower concentrations. This difference remained significant $(\mathrm{P}=0.04)$ after allowance for differences in ciclosporin formulation $(\mathrm{P}=0.97)$ and concentration $(\mathrm{P}=0.38)$ (table 5). Figure 5 shows this relation, which suggests that the benefit in graft survival is maximal when the tacrolimus concentration is $\leq 10 \mathrm{ng} / \mathrm{ml}$.

The benefit of tacrolimus in reducing acute rejection did not vary after allowance for tacrolimus concentration $(\mathrm{P}=0.77)$, ciclosporin formulation $(\mathrm{P}=0.99)$, ciclosporin concentration $(\mathrm{P}=0.14)$, or different antiproliferative agents $(\mathrm{P}=0.98)$ (table 5).

For patients with new diabetes mellitus, risk did not differ by antiproliferative agent $(\mathrm{P}=0.29)$ or steroid dose $(\geq 10 \mathrm{mg} /$ day $v$ $<10 \mathrm{mg}$ /day at three months; adjusted relative risk 1.36, 0.32 to $5.71 ; \mathrm{P}=0.27)$. The increased risk of new diabetes with tacrolimus compared with ciclosporin was not uniform across all trials (fig 4) but increased with increasing tacrolimus concentrations (table 5) and seemed to be higher when tacrolimus was compared with ciclosporin solution rather than microemulsion. This is a biologically implausible finding and suggests confounding by trial design. Early comparative trials used both ciclosporin solution and higher tacrolimus concentrations; figure 6 illustrates this relation. When we repeated the analysis to reflect contemporary practice, restricting it to trials using microemulsion ciclosporin, the effect of increasing tacrolimus concentration remained significant $(\mathrm{P}=0.003)$ after allowance for differences in antiproliferative agent $(\mathrm{P}=0.73)$, further suggesting that risk of diabetes rises with tacrolimus exposure rather than ciclosporin formulation. Figure 6 suggests that at a cut-off point for tacrolimus concentrations of $\leq 10 \mathrm{ng} / \mathrm{ml}$, which maximises the relative benefit on graft survival, the excess risk of diabetes can be minimised. Unfortunately, inconsistent reporting of clinical details across all trials (only 10 trials that reported diabetes also reported steroid dosage) prevented the intended more complex analyses.

\section{Discussion}

\section{Summary of key findings}

Compared with ciclosporin, treating kidney transplant recipients with tacrolimus resulted in a substantial improvement in graft survival-a 44\% reduction in graft loss (censored for death) within the first six months, an effect revealed for the first time by this meta-analysis and not evident when considering each trial in isolation. Treating with tacrolimus led to $31 \%$ fewer patients having acute rejection and 51\% fewer having severe rejection that needed treatment more intensive than steroids, within the first year.

Evidence from meta-regression suggested that benefit in graft survival diminished when higher concentrations of tacrolimus were targeted but was unaltered by differences in ciclosporin formulation, ciclosporin concentration, or antiprolif- 
erative co-interventions. However, none of these factors significantly altered the risk of acute rejection.
Tacrolimus treated patients were between two and three times more likely to develop new diabetes mellitus requiring

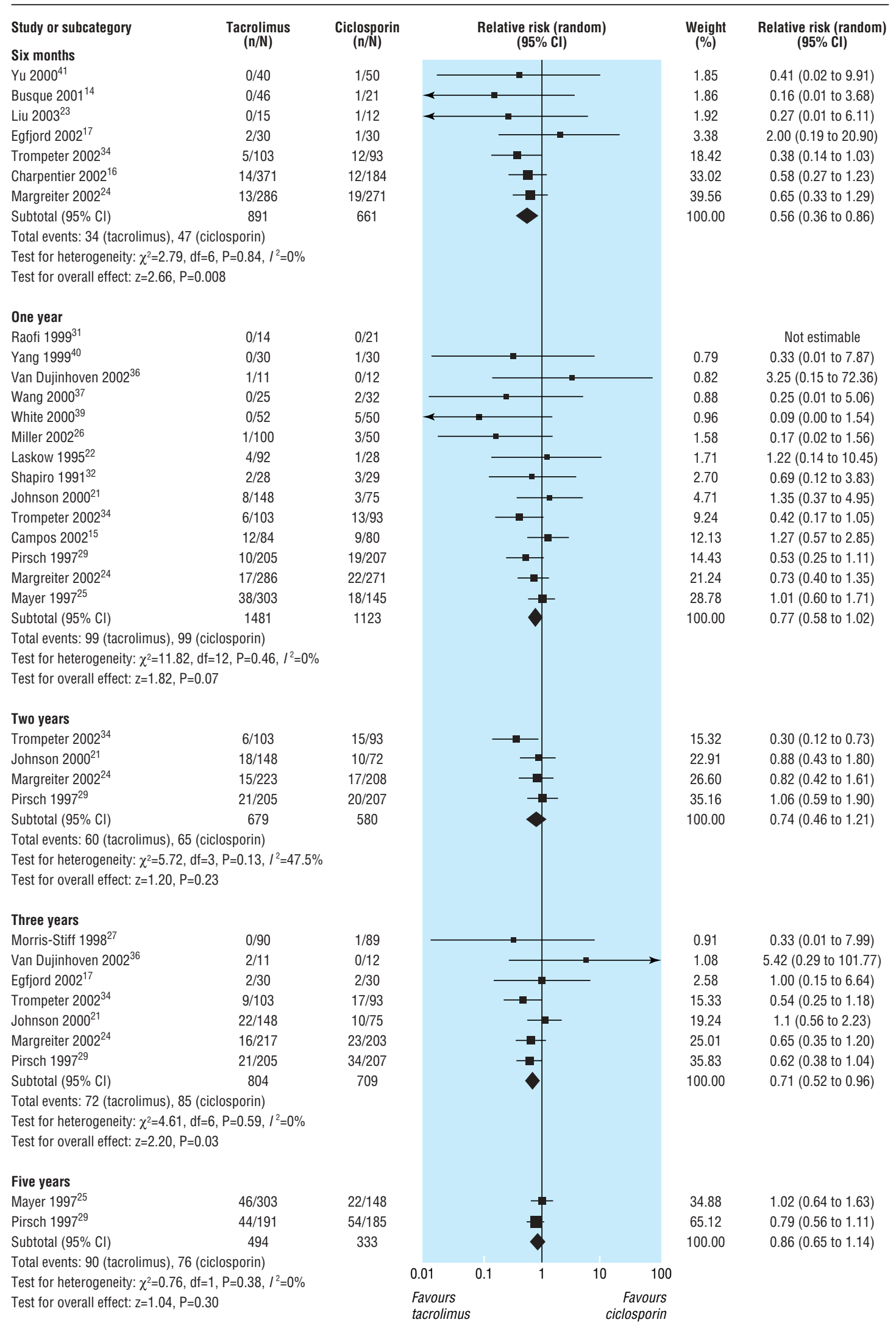

Fig 2 Graft loss, censored for death 
Table 2 Additional results of meta-analysis: transplant centred outcomes

\begin{tabular}{|c|c|c|c|c|c|}
\hline \multirow[b]{2}{*}{ Outcome, by time after transplantation } & \multirow[b]{2}{*}{ No of trials } & \multirow[b]{2}{*}{ No of participants } & \multirow[b]{2}{*}{ Relative risk $(95 \% \mathrm{CI})^{*}$} & \multicolumn{2}{|c|}{ Tests for heterogeneity } \\
\hline & & & & $P$ value & $P^{2}(\%)$ \\
\hline \multicolumn{6}{|l|}{ Acute rejection (all) } \\
\hline Three months & 5 & 248 & 0.95 (0.44 to 2.08$)$ & 0.09 & 49.9 \\
\hline Six months & 10 & 1778 & 0.68 (0.60 to 0.78$)$ & 0.73 & 0 \\
\hline One year & 14 & 2751 & 0.69 (0.60 to 0.79$)$ & 0.16 & 27.2 \\
\hline \multicolumn{6}{|l|}{ Acute rejection (biopsy proved) } \\
\hline Six months & 7 & 1605 & 0.68 (0.48 to 0.96$)$ & 0.02 & 59.2 \\
\hline One year & 8 & 1944 & 0.61 (0.52 to 0.72$)$ & 0.29 & 16.7 \\
\hline \multicolumn{6}{|l|}{ Graft loss or death with functioning graft } \\
\hline Six months & 8 & 1702 & 0.60 (0.42 to 0.86$)$ & 0.99 & 0 \\
\hline One year & 14 & 2604 & 0.90 (0.71 to 1.13 ) & 0.49 & 0 \\
\hline Two years & 4 & 1259 & 0.77 (0.55 to 1.08$)$ & 0.21 & 34.1 \\
\hline Three years & 7 & 1513 & 0.74 (0.59 to 0.93$)$ & 0.86 & 0 \\
\hline Five years & 2 & 827 & 0.94 (0.77 to 1.14$)$ & 0.91 & 0 \\
\hline \multicolumn{6}{|l|}{ Death (all cause) } \\
\hline Six months & 8 & 1702 & 0.68 (0.36 to 1.31$)$ & 0.92 & 0 \\
\hline One year & 14 & 2604 & 1.05 (0.66 to 1.68$)$ & 0.31 & 14.2 \\
\hline Two years & 4 & 1262 & 0.78 (0.48 to 1.27$)$ & 0.45 & 0 \\
\hline Three years & 6 & 1290 & 0.91 (0.59 to 1.40$)$ & 0.91 & 0 \\
\hline Five years & 2 & 827 & 1.00 (0.75 to 1.33$)$ & 0.47 & 0 \\
\hline \multicolumn{6}{|l|}{ Chronic allograft nephropathy } \\
\hline \multirow[t]{2}{*}{ One year } & 3 & 914 & 0.28 (0.11 to 0.68$)$ & 0.75 & 0 \\
\hline & & \multicolumn{4}{|c|}{ Weighted mean difference $(95 \% \mathrm{Cl})^{*}$} \\
\hline \multicolumn{6}{|l|}{ Serum creatinine (mg/dl) } \\
\hline Six months & 8 & 1216 & $-0.14(-0.27$ to -0.01$)$ & $<0.04$ & 52.0 \\
\hline One year & 8 & 837 & $-0.12(-0.36$ to 0.12$)$ & $<0.001$ & 91.1 \\
\hline Three years & 2 & 506 & $0.03(-0.08$ to 0.14$)$ & 0.25 & 23.8 \\
\hline
\end{tabular}

*Relative risk values $<1$ and weighted mean difference values $<0$ favour treatment with tacrolimus.

insulin and also to have neurological side effects, whereas those taking ciclosporin had more cosmetic side effects. Risk of diabetes rose when higher concentrations of tacrolimus were targeted.

\section{Strengths and limitations}

This systematic review used widely inclusive criteria, to allow exploration of differences in effect that might arise as a result of obvious clinical and design differences among the trials and also to highlight and summarise the totality of randomised trial evidence available. This approach led to identification of a large number of trials (30) involving 4102 participants, including unpublished and non-English language data sources. Confining a meta-analysis to published or English language data alone has previously been shown to overestimate positive treatment effects. ${ }^{44}$

Adverse effects of treatment were inconsistently reported. Most trials did not report new cases of diabetes that could be controlled by diet or oral hypoglycaemic agents; they used high diagnostic thresholds, recording only those cases that needed sustained insulin treatment. In addition, often the prevalent cases rather than incident cases were reported, with no indication of the numbers of patients with diabetes before transplantation. Both these aspects introduced bias and are likely to contribute to the underestimation of the true burden of disturbed glucose metabolism after transplantation. The value of increasing available evidence of potential harms associated with interventions has been widely recognised recently. ${ }^{45}$ This review shows that clearly defined, standardised, consistently used and reported clinical endpoints, particularly for harms, would greatly enhance interpretation of trial evidence by clinicians and consumers. ${ }^{47} 48$

The use of meta-regression to explore sources of heterogeneity in the meta-analysis was justified, as heterogeneity tests have low power. ${ }^{49}$ The relation described by meta-regression is an observational association across trials and does not have the benefit of randomisation to underpin interpretation of results. Hence an association identified with one trial characteristic may in reality reflect a true association with other correlated characteristics, which may be unknown. The finding that trials that used ciclosporin microemulsion showed a significantly lower risk of post-transplantation diabetes than those that used ciclosporin solution, with no difference in graft loss or acute rejection, may be an example of such misclassification, and hence our interpretation is guarded. That higher concentrations of tacrolimus altered the risk of graft loss towards that experienced by patients on ciclosporin, decreasing the advantage of tacrolimus, we feel is more biologically plausible, given what is known of the complex interplay between calcineurin nephrotoxicity, chronic allograft nephropathy, and infection, ${ }^{50}{ }^{51}$ as well as the evidence that higher doses of calcineurin inhibitors increase progression of histological markers of graft damage. ${ }^{52}{ }^{53}$ Our meta-regression was limited by available data, so we may have failed to identify clinically important differences between subgroups that do exist. $^{54}$

\section{Clinical implications}

On the basis of this analysis, treating 100 recipients at low risk (such as adult, well matched, first transplants) with tacrolimus instead of ciclosporin would avoid six cases of acute rejection; this rises to 17 cases if we consider recipients at high risk (such as sensitised recipients of subsequent grafts, or children). Tacrolimus treatment would avoid one low risk patient but three high risk patients losing their grafts. In contrast, treating with tacrolimus would cause an extra five recipients excess harm by causing them to develop insulin dependent diabetes (table 6). Evidence from meta-regression suggests that targeting tacrolimus concentrations lower than $10 \mathrm{ng} / \mathrm{ml}$ will minimise graft loss and temper the increased risk of diabetes mellitus without increasing the risk of acute rejection (fig 5 and fig $6^{6}$ ). 
One other meta-analysis of four randomised trials comparing tacrolimus with ciclosporin solution was published in $1999,{ }^{55}$ and more recently a review examined post-transplant diabetes in solid organ transplant recipients, including a seven trial meta-analysis of randomised data for kidney recipients, whereas we were able to identify 15 trials.$^{56}$ Our results largely concur with this previous work and with recent clinical guidelines published in the United Kingdom, ${ }^{57}$ although with a larger number of trials to analyse our estimates have greater precision, and we have greatly extended the range of outcomes assessed.

\section{Future directions}

Our goal was to distil the body of evidence amassed over more than a decade of large multinational comparative randomised trials of the two calcineurin inhibitors, to highlight the deficits in knowledge, and so set the research priorities for the coming decade. Insufficient information was available to permit formal economic analyses, and a general failure to consider global quality of life for transplant recipients existed. The next step must be to construct a decision analysis, using this comprehensive summary of evidence, attaching utilities to the positive and adverse outcomes associated with each drug. This would provide clinicians and patients with an algorithm trading off graft survival against the impact of diabetes and other complications of immunosuppression, so tailoring the choice of calcineurin inhibitor to an individual patient's circumstances.

\section{Conclusions}

Tacrolimus is superior to ciclosporin in preventing acute rejection after kidney transplantation, and we have shown for the first time that tacrolimus treated patients have improved early graft survival, although this is at the expense of increased diabetes and neurological and gastrointestinal side effects. In applying this evidence to patients, the choice of calcineurin inhibitor for an individual patient is neither automatic nor straightforward, as risks of benefit and of drawbacks of each treatment must be balanced.

We acknowledge the help and support of all members of the Cochrane Renal Group and thank all report authors who responded to our enquiries, particularly those who provided further information about their work. Preliminary reports of this systematic review were presented at the 21st annual scientific meeting of the Transplantation Society of Australia and New Zealand, Canberra 2003, and the World Congress of Nephrology, Berlin 2003. The review will appear in extended version in the Cochrane Database of Systematic Reviews, 2005, issue 4

Contributors: ACW conceived, designed, and developed the protocol and search strategy for the review; contacted authors and pharmaceutical companies; identified and extracted data from included trials; analysed and interpreted the results; and wrote the manuscript. RCW and RST identified and extracted data from included trials and participated in interpretation of results and revision of the manuscript. JRC contributed to the protocol development and participated in interpretation of results and revision of the manuscript. JCC contributed to the conception, design, and development of the protocol, the analysis and interpretation of the results, and the drafting and revision of the manuscript. ACW is the guarantor.

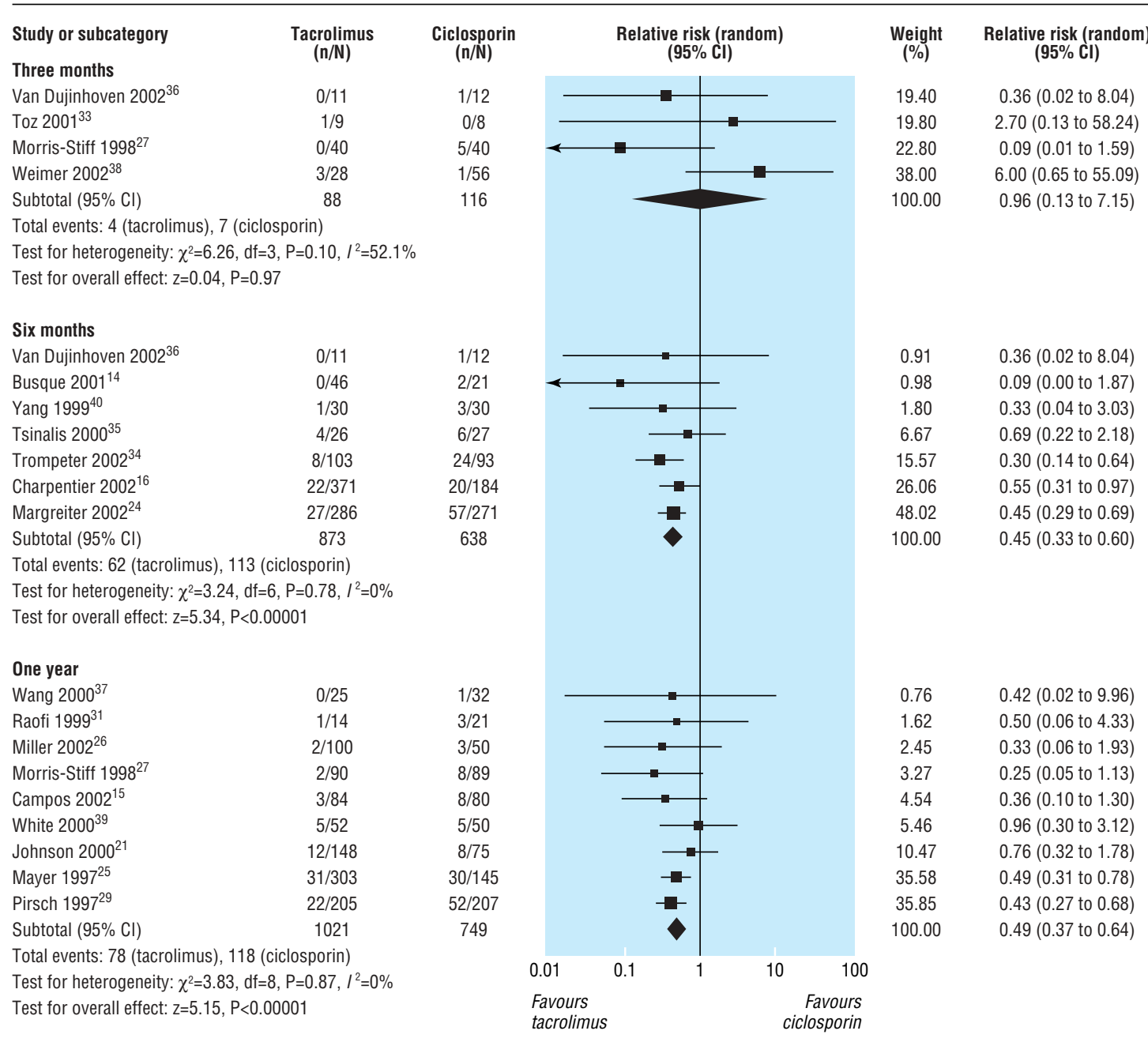

Fig 3 Steroid resistant acute rejection 
Table 3 Additional results of meta-analysis: complications and adverse reactions

\begin{tabular}{|c|c|c|c|c|c|}
\hline \multirow[b]{2}{*}{ Outcome, by time after transplantation } & \multirow[b]{2}{*}{ No of trials } & \multirow[b]{2}{*}{ No of participants } & \multirow[b]{2}{*}{ Relative risk $(95 \% \mathrm{Cl})^{*}$} & \multicolumn{2}{|c|}{ Tests for heterogeneity } \\
\hline & & & & $P$ value & $P^{2}(\%)$ \\
\hline \multicolumn{6}{|l|}{ Infection (all cause) } \\
\hline Six months & 4 & 380 & $1.05(0.87$ to 1.28$)$ & 0.88 & 0 \\
\hline One year & 5 & 1422 & 0.99 (0.90 to 1.07$)$ & 0.48 & 0 \\
\hline \multicolumn{6}{|l|}{ Cytomegalovirus infection } \\
\hline Six months & 3 & 1335 & 0.78 (0.60 to 1.01$)$ & 0.43 & 0 \\
\hline One year & 6 & 1005 & $0.97(0.72$ to 1.29$)$ & 0.54 & 0 \\
\hline \multicolumn{6}{|l|}{ Malignancy (all) } \\
\hline Six months & 2 & 753 & $1.21(0.27$ to 5.47$)$ & 0.64 & 0 \\
\hline One year & 7 & 1765 & 0.80 (0.37 to 1.73$)$ & 0.89 & 0 \\
\hline Three years & 2 & 608 & $0.91(0.52$ to 1.60$)$ & 0.67 & 0 \\
\hline Five years & 2 & 860 & $1.06(0.70$ to 1.60$)$ & 0.86 & 0 \\
\hline \multicolumn{6}{|c|}{ Lymphoma/post-transplant lymphoproliferative disorder } \\
\hline One year & 4 & 866 & $0.77(0.29$ to 2.08$)$ & 0.90 & 0 \\
\hline Two years & 2 & 635 & 0.88 (0.27 to 2.95$)$ & 0.72 & 0 \\
\hline Three years & 2 & 608 & 0.77 (0.31 to 1.93$)$ & 0.82 & 0 \\
\hline Five years & 2 & 860 & $1.22(0.46$ to 3.22$)$ & 0.88 & 0 \\
\hline \multicolumn{6}{|c|}{ Diabetes mellitus-sustained irreversible insulin dependent } \\
\hline Six months & 6 & 915 & 2.61 (1.16 to 5.85$)$ & 0.53 & 0 \\
\hline One year & 11 & 1956 & $1.70(1.04$ to 2.78$)$ & 0.14 & 32.7 \\
\hline Three years & 2 & 447 & $3.26(1.62$ to 6.57$)$ & 0.66 & 0 \\
\hline \multicolumn{6}{|l|}{ Hypercholesterolaemia } \\
\hline \multirow[t]{2}{*}{ Six months } & 2 & 1112 & $0.41(0.24$ to 0.71$)$ & 0.52 & 0 \\
\hline & & & ighted mean difference $(95 \%$ & & \\
\hline \multicolumn{6}{|l|}{ Total cholesterol (mg/dl) } \\
\hline Six months & 3 & 722 & $-22.39(-29.77$ to -15.06$)$ & 0.86 & 0 \\
\hline \multirow[t]{2}{*}{ One year } & 3 & 183 & $-30.89(-67.95$ to -6.56$)$ & 0.0004 & 87.1 \\
\hline & & & Relative risk $(95 \% \mathrm{Cl})^{*}$ & & \\
\hline \multicolumn{6}{|l|}{ Adverse reactions, by system } \\
\hline \multicolumn{6}{|l|}{ Neurological: } \\
\hline Tremor & 6 & 2152 & 2.18 (1.50 to 3.17$)$ & 0.07 & 50.6 \\
\hline Insomnia & 3 & 980 & 1.03 (0.83 to 1.28$)$ & 0.38 & 0 \\
\hline Headache & 3 & 980 & $1.23(1.00$ to 1.52$)$ & 0.52 & 0 \\
\hline Paraesthesia & 2 & 532 & 1.64 (0.85 to 3.16$)$ & 0.30 & 6.9 \\
\hline \multicolumn{6}{|l|}{ Biochemical: } \\
\hline Hypomagnesaemia & 2 & 753 & 2.99 (1.78 to 5.02) & 0.38 & 0 \\
\hline Cholestasis & 2 & 647 & 0.23 (0.05 to 1.05$)$ & 0.47 & 0 \\
\hline Hyperkalaemia & 2 & 568 & 1.33 (0.97 to 1.82$)$ & 0.94 & 0 \\
\hline \multicolumn{6}{|l|}{ Gastrointestinal: } \\
\hline Constipation & 3 & 980 & 0.83 (0.69 to 0.99$)$ & 0.39 & 0 \\
\hline Diarrhoea & 7 & 1343 & 1.98 (1.03 to 3.83$)$ & 0.0006 & 74.8 \\
\hline Nausea & 2 & 852 & $1.04(0.84$ to 1.30$)$ & 0.93 & 0 \\
\hline Dyspepsia & 3 & 980 & $1.31(1.00$ to 1.70$)$ & 0.85 & 0 \\
\hline Vomiting & 3 & 980 & 1.41 (1.05 to 1.89$)$ & 0.35 & 5.6 \\
\hline \multicolumn{6}{|l|}{ Cosmetic: } \\
\hline Hirsutism & 4 & 1613 & 0.04 (0.01 to 0.15$)$ & 0.90 & 0 \\
\hline Gingival hyperplasia & 5 & 1673 & 0.14 (0.06 to 0.34$)$ & 0.78 & 0 \\
\hline Alopecia & 2 & 969 & 10.55 (2.91 to 38.23$)$ & 0.87 & 0 \\
\hline
\end{tabular}

* Relative risk values $<1$ and weighted mean difference values $<0$ favour treatment with tacrolimus.

Funding: The Cochrane Renal Group receives financial support from several sources including government and industry. These funds go into a general fund managed by the Children's Hospital at Westmead. These funds are used to support key activities including hand-searching, the development of a trials registry, training and support for reviewers conducting reviews, and consumer participation in the group. Those contributing funds have no rights of authorship or publication. The authors of the review retain the right to interpretation of the results and the right to publish. Funding sources are/have been Amgen Australia, Amgen Inc, Aventis Pharma (past), Janssen-Cilag (distributors of tacrolimus), Novartis Pharmaceuticals (manufacturers of ciclosporin solution and microemulsion), Servier (past), Wyeth Australia, Australian Department of Health and Ageing, Australian Kidney Foundation, Australian and New Zealand Society of Nephrology, National Health, and Medical Research Council of Australia.

Competing interests: ACW and JCC belong to the Cochrane Renal Group (see above under funding). ACW receives indirect support for infrastructure costs associated with unrelated research with ANZDATA, the dialysis and transplant registry of Australia and New Zealand, in the form of an unrestricted educational grant from Novartis Pharmaceuticals Australia (manufacturers of ciclosporin solution and microemulsion). JRC has advisory board and clinical trial involvement with Novartis (manufacturers of ciclosporin solution and microemulsion), Roche, Janssen-Cilag (distributors of tacrolimus), Fujisawa (manufacturers of tacrolimus), and Wyeth and has also been an invited speaker at national and international meetings sponsored by these companies. RST and RCW declare no competing interests.

Ethical approval: Not needed.

1 Chadban S. Transplantation: ANZDATA registry report 2003. Adelaide: Australian and New Zealand Dialysis And Transplant Registry, 2003:65.

2 Immunosuppression: 2004 annual report of the U.S. Organ Procurement and Transplantation Network and the scientific registry of transplant recipients: transplant data 1994-2003. Ann

Arbor, MI: HHS/HRSA/OSP/DOT and UNOS, 2004 .
Hong JC, Kahan BD. Immunosuppressive agents in organ transplantation: past, present, and future. Semin Nephrol 2000;20:108-25. 
Table 4 Subgroup analysis of trial methodology and design features for outcomes of graft loss censored for death, acute rejection, and new diabetes mellitus, within one year after transplantation

\begin{tabular}{|c|c|c|c|c|c|c|c|c|c|c|}
\hline \multirow[b]{2}{*}{ Potential bias } & \multirow[b]{2}{*}{ Subgroup strata } & \multicolumn{3}{|c|}{ Graft loss, censored for death } & \multicolumn{3}{|c|}{ Acute rejection } & \multicolumn{3}{|c|}{ New diabetes mellitus } \\
\hline & & $\begin{array}{l}\text { No of } \\
\text { trials }\end{array}$ & $\begin{array}{c}\text { Relative risk (95\% } \\
\text { Cl) }\end{array}$ & P value ${ }^{*}$ & $\begin{array}{l}\text { No of } \\
\text { trials }\end{array}$ & $\begin{array}{c}\text { Relative risk }(95 \% \\
\text { CI) }\end{array}$ & P value ${ }^{*}$ & $\begin{array}{l}\text { No of } \\
\text { trials }\end{array}$ & $\begin{array}{l}\text { Relative risk (95\% } \\
\text { CI) }\end{array}$ & P value ${ }^{\star}$ \\
\hline \multirow[t]{2}{*}{ Publication type } & $\begin{array}{l}\text { Abstract or non-peer } \\
\text { reviewed journal }\end{array}$ & 4 & 0.75 (0.31 to 1.79$)$ & 0.36 & 3 & 1.02 (0.57 to 1.82$)$ & 0.01 & 3 & 2.01 (0.94 to 4.29$)$ & 0.89 \\
\hline & Peer reviewed journal & 10 & 0.75 (0.55 to 1.02$)$ & & 11 & 0.64 (0.57 to 0.72$)$ & & 9 & 1.84 (0.95 to 3.57$)$ & \\
\hline \multirow[t]{2}{*}{ Trial quality } & $\begin{array}{l}\text { ITT analysis unclear or } \\
\text { not done }\end{array}$ & 8 & 0.70 (0.44 to 1.12$)$ & 0.86 & 7 & 0.77 (0.59 to 1.01) & 0.10 & 5 & 2.09 (1.11 to 3.96) & 0.87 \\
\hline & ITT analysis done & 6 & 0.83 (0.55 to 1.23$)$ & & 7 & 0.63 (0.54 to 0.73 ) & & 7 & 1.49 (0.74 to 3.01$)$ & \\
\hline \multirow[t]{2}{*}{ Trial population } & Low immunological risk & 5 & 0.48 (0.17 to 1.33$)$ & 0.35 & 4 & 0.65 (0.25 to 1.69) & 0.33 & 5 & 1.02 (0.46 to 2.27) & 0.16 \\
\hline & $\begin{array}{l}\text { Mixed and high } \\
\text { immunological risk }\end{array}$ & 9 & 0.79 (0.55 to 1.12) & & 10 & 0.66 (0.60 to 0.73$)$ & & 7 & 2.24 (1.43 to 3.49 ) & \\
\hline
\end{tabular}

ITT=intention to treat.

${ }^{*} \mathrm{P}$ value for test of interaction.

4 Meier-Kriesche HU, Schold JD, Srinivas TR, Kaplan B. Lack of improvement in renal allograft survival despite a marked decrease in acute rejection rates over the most recent era. Am J Transplant 2004;4:378-89.

5 Pascual M, Theruvath T, Kawai T, Tolkoff-Rubin N, Cosimi AB. Strategies to improve long-term outcomes after renal transplantation. N Engl J Med 2002;346:580-90.

Kasiske BL. Cardiovascular disease after renal transplantation. Semin Nephrol 2000;20:176-87.

7 Cosio FG, Larson TS. Cardiovascular disease after transplantation: do we know all of the variables? Am J Transplant 2003;3:915-6.

8 Denton MD, Magee CC, Sayegh MH. Immunosuppressive strategies in transplantation. Lancet 1999;353:1083-91.

9 Higgins JPT, Thompson SG, Deeks JJ, Altman DG. Measuring inconsistency in meta-analyses. BMJ 2003;327:557-60.

10 Deeks IJ, Altman DG, Bradburn MJ. Statistical methods for examining heterogeneity and combining results from several studies in meta-analysis. In: Foger M, Davey SG, Altman DG, eds. Systematic reviews in healthcare. 2nd ed. London: BMJ books, 2001:285311

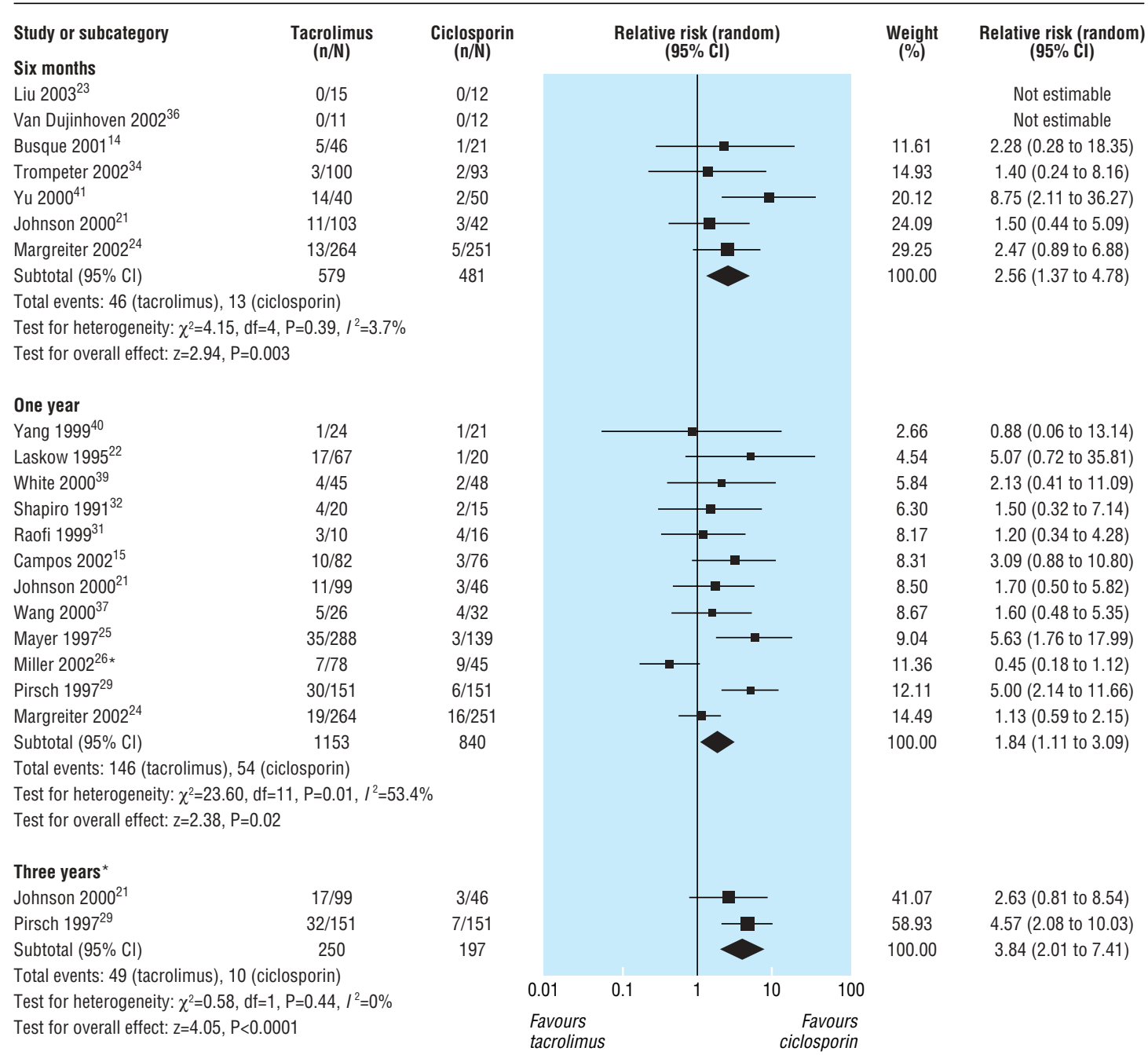

Fig 4 New requirement for insulin for $\geq 30$ days in previously non-diabetic participants. ${ }^{*}$ Trial Miller 2002 is largely responsible for the heterogeneity among trials at one year. Sensitivity analysis showed a relative risk of 2.19 (1.42 to 3.38), and much reduced heterogeneity ( $\mathrm{P}=0.18, P=27.5 \%)$ when this trial was removed from the analysis 
Table 5 Meta-regression*, to explore possible confounding effects on summary risk of graft loss censored for death, acute rejection, and new insulin treated diabetes mellitus, within one year after transplantation

\begin{tabular}{|c|c|c|c|c|c|c|c|c|c|c|c|c|}
\hline \multirow[b]{2}{*}{$\begin{array}{l}\text { Potential } \\
\text { confounder }\end{array}$} & \multicolumn{4}{|c|}{ Graft loss, censored for death } & \multicolumn{4}{|c|}{ Acute rejection } & \multicolumn{4}{|c|}{ New insulin treated diabetes mellitus } \\
\hline & $\begin{array}{l}\text { Unadjusted } \\
\text { ratio of } \\
\text { relative risk } \\
(95 \% \mathrm{Cl})\end{array}$ & $\begin{array}{c}P \\
\text { value }\end{array}$ & $\begin{array}{c}\text { Adjusted ratio } \\
\text { of relative risk } \\
(95 \% \mathrm{Cl}) \dagger\end{array}$ & $\begin{array}{c}P \\
\text { value }\end{array}$ & $\begin{array}{l}\text { Unadjusted } \\
\text { ratio of } \\
\text { relative risk } \\
(95 \% \mathrm{Cl})\end{array}$ & $\begin{array}{c}P \\
\text { value }\end{array}$ & $\begin{array}{c}\text { Adjusted ratio } \\
\text { of relative risk } \\
(95 \% \text { Cl) } \dagger\end{array}$ & $\begin{array}{c}P \\
\text { value }\end{array}$ & $\begin{array}{l}\text { Unadjusted ratio } \\
\text { of relative risk } \\
(95 \% \mathrm{Cl})\end{array}$ & $\begin{array}{c}P \\
\text { value }\end{array}$ & $\begin{array}{l}\text { Adjusted ratio of } \\
\text { relative risk } \\
(95 \% \mathrm{Cl}) \dagger\end{array}$ & $\begin{array}{c}P \\
\text { value }\end{array}$ \\
\hline $\begin{array}{l}\text { Ciclosporin } \\
\text { microemulsion v } \\
\text { solution }\end{array}$ & $\begin{array}{c}0.83 \\
(0.49 \text { to } 1.40)\end{array}$ & 0.48 & $\begin{array}{c}1.01 \\
(0.52 \text { to } 1.95)\end{array}$ & 0.97 & $\begin{array}{c}1.10 \\
\text { (0.88 to } 1.36)\end{array}$ & 0.40 & $\begin{array}{c}0.99 \\
(0.78 \text { to } 1.28)\end{array}$ & 0.99 & $\begin{array}{c}0.35 \\
(0.17 \text { to } 0.74)\end{array}$ & 0.006 & $\begin{array}{c}0.30 \\
(0.13 \text { to } 0.66)\end{array}$ & 0.003 \\
\hline $\begin{array}{l}\text { Ciclosporin } \\
\text { concentration, } \\
\text { per } 25 \mathrm{ng} / \mathrm{ml}\end{array}$ & $\begin{array}{c}1.02 \\
\text { (0.89 to } 1.17)\end{array}$ & 0.76 & $\begin{array}{c}0.92 \\
(0.77 \text { to } 1.11)\end{array}$ & 0.38 & $\begin{array}{c}1.06 \\
(1.01 \text { to } 1.11)\end{array}$ & 0.02 & $\begin{array}{c}1.07 \\
\text { (0.98 to 1.17) }\end{array}$ & 0.14 & $\begin{array}{c}1.03 \\
\text { (0.79 to } 1.33)\end{array}$ & 0.83 & $\begin{array}{c}1.05 \\
(0.86 \text { to } 1.29)\end{array}$ & 0.61 \\
\hline $\begin{array}{l}\text { Tacrolimus } \\
\text { concentration, } \\
\text { per } 1 \mathrm{ng} / \mathrm{ml} \neq\end{array}$ & $\begin{array}{c}1.20 \\
(1.02 \text { to } 1.41)\end{array}$ & 0.04 & $\begin{array}{c}1.33 \\
(1.02 \text { to } 1.74)\end{array}$ & 0.04 & $\begin{array}{c}1.04 \\
(0.99 \text { to } 1.08)\end{array}$ & 0.10 & $\begin{array}{c}0.98 \\
(0.83 \text { to } 1.14)\end{array}$ & 0.77 & $\begin{array}{c}1.20 \\
(1.05 \text { to } 1.38)\end{array}$ & 0.007 & $\begin{array}{c}1.18 \\
\text { (0.97 to } 1.45)\end{array}$ & 0.10 \\
\hline $\begin{array}{c}\text { Mycophenolate } v \\
\text { azathioprine }\end{array}$ & $\begin{array}{c}0.73 \\
\text { (0.23 to } 2.29 \text { ) }\end{array}$ & 0.59 & NA & NA & $\begin{array}{c}1.47 \\
(0.88 \text { to } 2.48)\end{array}$ & 0.14 & $\begin{array}{c}0.99 \\
(0.52 \text { to } 1.91)\end{array}$ & 0.98 & $\begin{array}{c}0.53 \\
(0.12 \text { to } 1.69)\end{array}$ & 0.29 & NA & NA \\
\hline
\end{tabular}

${ }^{*}$ Results are expressed as the ratio of the relative risk with each potential modifier, compared with the relative risk of the reference category of that confounder. Ratios $<1$ correspond to a smaller treatment relative risk for trials with that reference characteristic, so reflecting larger benefit for that characteristic.

†Adjusted ratio for each outcome is for multivariate model containing all explanatory variables that have an adjusted ratio quoted. NA=not available. Insufficient data reported across trials, so limiting the number of possible confounders that could be controlled for in the multivariate model. Multivariate model limited to those factors felt, a priori, to be of most clinical interest and have greatest potential to confound the analysis.

łCiclosporin and tacrolimus concentrations calculated by taking weighted average of stated "intention to treat" target range concentrations, at the 12 hour post-dose nadir, over the first year after transplantation, in $\mathrm{ng} / \mathrm{ml}$.

11 Egger M, Davey SG, Schneider M, Minder C. Bias in meta-analysis detected by a simple, graphical test. $B M J$ 1997;315:629-34.

12 Agha IA, Alvarez A, Lopez L, Hardinger K, Torrence S, Miller B, et al. Human polyoma virus infects a high proportion of renal allograft recipients and the incidence is not virus infects a high prop.

2001;12:847A

13 Baskin E, Colak T, Karakayali H, Ozdemir FN, Saatci U, Haberal M. Changes in serum cholesterol and triglyceride level in renal transplant recipient treated with cyclosporine or tacrolimus [abstract]. XIXth International Congress of the Transplantation Society, Miami, FL, 25-30 August, 2002.

14 Busque S, Shoker A, Landsberg D, McAlister V, Halloran P, Shapiro J, et al. Canadian multicentre trial of tacrolimus/azathioprine/steroids versus tacrolimus/ mycophenolate mofetil/steroids versus Neoral/mycophenolate mofetil/steroids in renal transplantation. Transplant Proc 2001;33:1266-7.

15 Campos H, Filho M. One-year follow-up of a Brazilian randomized multicenter study comparing tacrolimus versus cyclosporine in kidney transplantation. Transplant Proc 2002;34:1656-8.

16 Charpentier B. A three arm study comparing immediate tacrolimus therapy with ATC induction therapy followed by either tacrolimus or cyclosporine in adult renal ransplant recipients. Transplant Proc 2002:34:1625-6.

17 Egfjord M, Ladefoged J, Olgaard K. Similar frequency of acute rejection, graft and patient survival in quadruple therapy with tacrolimus versus cyclosporin in combination with prednisone, mycophenolate mofetil, and atgam after renal allotransplantation [abstract]. XIXth International Congress of the Transplantation Society, Miami, FL, 25-30 August, 2002

18 El Haggan W, Barthe N, Vendrely B, Chauveau P, Berger F, Aparicio M, et al. One year evolution of bone mineral density in kidney transplant recipients receiving tacrolimus versus cyclosporine. Transplant Proc 2002;34:1817-8.

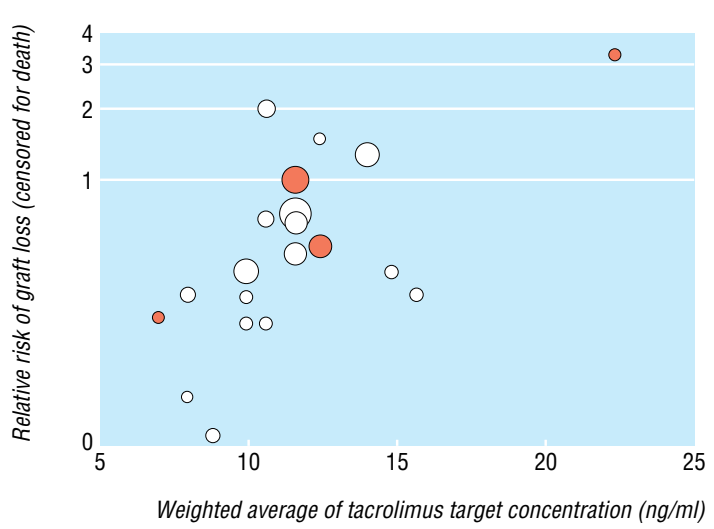

Fig 5 Relative risk of graft loss (censored for death) versus weighted average of tacrolimus concentrations (calculated by using the midpoint of each trial's declared intention to treat target range at the 12 hour post-dose nadir) over the first year after transplantation. Each circle represents a trial, with area proportional to inverse of variance of estimated treatment effect (larger circles show trials given more weight in meta-analysis). Colour of circles represents formulation of ciclosporin used in each trial: red circles are ciclosporin solution; white circles are ciclosporin microemulsion
19 Heering P, Ivens K, Aker S, Grabensee B. Distal tubular acidosis induced by FK506. Clin Transplant 1998;12:465-71.

20 Ichimaru N, Takahara S, Kokado Y, Wang JD, Hatori M, Kameoka H, et al. Changes in lipid metabolism and effect of simvastatin in renal transplant recipients induced by cyclosporine or tacrolimus. Atherosclerosis 2001:158:417-23.

21 Johnson C, Ahsan N, Gonwa T, Halloran P, Stegall M, Hardy M, et al. Randomized trial of tacrolimus (Prograf) in combination with azathioprine or mycophenolate mofetil versus cyclosporine (Neoral) with mycophenolate mofetil after cadaveric kidney transplantation. Transplantation 2000;69:834-41

22 Laskow DA, Vincenti F, Neylan J, Mendez R, Matas A. Phase II FK 506 multicenter concentration control study: one-year follow-up. Transplant Proc 1995;27:809-11.

23 Liu B, Lin ZB, Ming CS, Zhang WJ, Chen ZS, Sha B, et al. Randomized trial of tacrolimus in combination with mycophenolate mofetil versus cyclosporine with mycophenolate mofetil in cadaveric renal transplant recipients with delayed graft function. Transplant Proc 2003;35:87-8

24 Margreiter R, European Tacrolimus vs Ciclosporin Microemulsion Renal Transplantation Study Group. Efficacy and safety of tacrolimus compared with ciclosporin microvin Stu Group. emalsion in

25 Mayer AD, Dmitrewski J, Squifflet JP, Besse T, Grabensee B, Klein B, et al. Multicenter randomized trial comparing tacrolimus (FK506) and cyclosporine in the prevention of renal allograft rejection: a report of the European Tacrolimus Multicenter Renal Study Group. Transplantation 1997;64:436-43.

26 Miller J, Burke GW, Ciancio G, Blomberg BB, Rosen A, Roth D, et al. Randomized trial of three different immunosuppressive regimens to prevent chronic renal allograft rejection [abstract]. XIXth International Congress of the Transplantation Society, Miami, FL, 25-30 August, 2002.

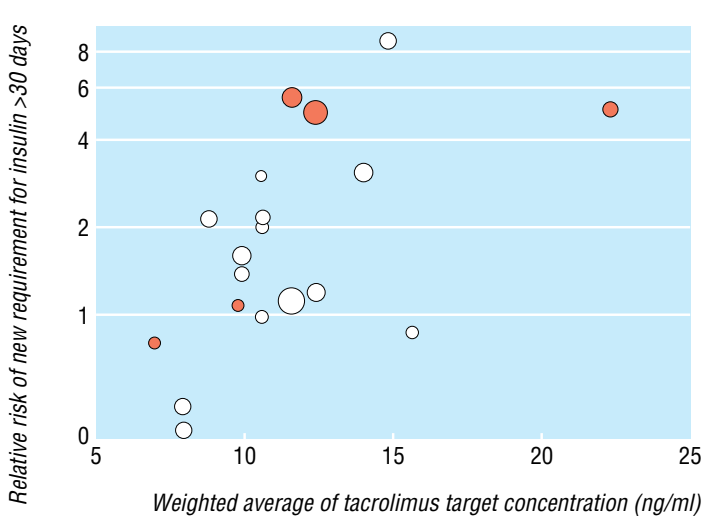

Fig 6 Relative risk of diabetes mellitus requiring insulin treatment for $>30$ days in previously non-diabetic patients versus weighted average of tacrolimus concentrations (calculated by using the midpoint of each trial's declared intention to treat target range at the 12 hour post-dose nadir) over the first year after transplantation. Each circle represents a trial, with area proportional to inverse of variance of estimated treatment effect (larger circles show trials given more weight in meta-analysis). Colour of circles represents formulation of ciclosporin used in each trial: red circles are ciclosporin solution; white circles are ciclosporin microemulsion 
Table 6 Applicability in clinical practice: projected recipient numbers with acute rejection, graft loss, and new sustained diabetes mellitus requiring insulin per hundred patients treated with either tacrolimus or ciclosporin

\begin{tabular}{|c|c|c|c|c|c|c|c|c|c|}
\hline \multirow{3}{*}{$\begin{array}{l}\text { Immunological risk } \\
\text { before } \\
\text { transplantation }\end{array}$} & \multicolumn{9}{|c|}{ Absolute risk of outcome per 100 treated recipients } \\
\hline & \multicolumn{3}{|c|}{ Acute rejection* } & \multicolumn{3}{|c|}{ Graft loss } & \multicolumn{3}{|c|}{ New diabetes mellitus requiring insulin } \\
\hline & Ciclosporin & Tacrolimus & $\begin{array}{c}\text { Avoided } \\
\text { cases }\end{array}$ & Ciclosporin & Tacrolimus & $\begin{array}{c}\text { Avoided } \\
\text { casest }\end{array}$ & Ciclosporin & Tacrolimus & Excess cases \\
\hline Low & 20 & 14 & 6 & 6 & 5 & 1 & 6 & 11 & 5 \\
\hline Medium & 40 & 28 & 12 & 9 & 7 & 2 & 6 & 11 & 5 \\
\hline High & 55 & 38 & 17 & 11 & 8 & 3 & 6 & 11 & 5 \\
\hline
\end{tabular}

${ }^{*}$ Ciclosporin rates for acute rejection calculated by using summary rate in ciclosporin (control) arms of trials. Trials were grouped by immunological risk of participating population, based on known associations: age, race, panel reactive antibody level, previous transplantation. These estimates were corroborated with current cohort data (ANZDATA). ${ }^{2}$ Rates of graft loss and diabetes were derived from the summary rates of these outcomes in the ciclosporin (control) arms of trials reported at one year. Tacrolimus rate calculated on basis of overall relative risks of 0.69 for acute rejection, 0.77 for death censored graft loss, and 1.86 for new onset diabetes mellitus requiring insulin for $\geq 30$ days, all at one year after transplantation.

tCalculated as absolute risk reduction or increase.

27 Morris-Stiff G, Ostrowski K, Balaji V, Moore R, Darby C, Lord R, et al. Prospective randomised study comparing tacrolimus (Prograf) and cyclosporin (Neoral) as primary immunosuppression in cadaveric renal transplants at a single institution: interim report of the first 80 cases. Transpl Int 1998;11:S334-6.

28 Nichelle L, Canet S, Garrigue V, Chong G, Mourad G. Arterial hypertension in renal transplant recipients treated with tacrolimus or cyclosporine-neoral. Transplant Proc 2002;34:2824-5.

29 Pirsch JD, Miller J, Deierhoi MH, Vincenti F, Filo RS, Kidney Transplant Study Group. A comparison of tacrolimus (FK506) and cyclosporine for immunosuppression after cadaveric renal transplantation. Transplantation 1997;63:977-83.

30 Radermacher J, Meiners M, Bramlage C, Kliem V, Behrend M, Schlitt HJ, et al Pronounced renal vasoconstriction and systemic hypertension in renal transplan patients treated with cyclosporin A versus FK 506. Transpl Int 1998;11:3-10.

31 Raofi V, Holman DM, Coady N, Vazquez E, Dunn TB, Bartholomew AM, et al. A prospective randomized trial comparing the efficacy of tacrolimus versus cyclosporine in black recipients of primary cadaveric renal transplants. Am J Surg 1999;177:299-302.

32 Shapiro R, Jordan M, Scantlebury V, Fung J, Jensen C, Tzakis A, et al. FK 506 in clinical kidney transplantation. Transplant Proc 1991;23:3065-7.

33 Toz H, Duman S, Sen S, Hoscoskun C, Ozbek S, Basdemir G, et al. Tacrolimus- vs cyclosporin microemulsion-based treatment in renal transplantation: comparison with cyclosporin microemulsion-based treatment in renal transplantation: com
third month protocol biopsies [abstract]. J Am Soc Nephrol 2001;12:950A.

34 Trompeter R, Filler G, Webb NJ, Watson AR, Milford DV, Tyden G, et al. Randomized trial of tacrolimus versus cyclosporin microemulsion in renal transplantation. Pediatr Nephrol 2002;17:141-9.

35 Tsinalis D, Binet I, Dickenmann M, Steiger J, Brunner F, Thiel G. Cost of medical care after renal transplantation comparing cyclosporine-mycophenolate to tacrolimusazathioprine-a randomised controlled study [abstract]. XVIIII International Congress of the Transplantation Society, Rome, 27 August-1 September, 2000.

36 Van Duijnhoven EM, Christiaans MH, Boots JM, Nieman FH, Wolffenbuttel BH, van Hooff JP. Glucose metabolism in the first 3 years after renal transplantation in patients receiving tacrolimus versus cyclosporine-based immunosuppression. J Am Soc Nephrol 2002;13:213-20

37 Wang XH, Tang XD, Xu D. Tacrolimus vs CyA Neoral in combination with MMF and steroids after cadaveric renal transplantation. Transplant Proc 2000;32:1702-3.

38 Weimer R, Streller S, Staak A, Heilke M, Li D, Dietrich H, et al. Effects of three immunosuppressive regimens on $\mathrm{CD} 4$ helper function, B cell monocyte and cytokine

\section{What is already known on this topic}

Both tacrolimus and ciclosporin improve graft survival, but tacrolimus reduces acute rejection in kidney transplant recipients more than ciclosporin does

Tacrolimus is associated with more diabetes and neurotoxicity but less hypertension, dyslipidaemia, and cosmetic side effects than ciclosporin

\section{What this study adds}

Tacrolimus improves graft survival compared with ciclosporin, with a $44 \%$ reduction in graft loss (censored for death) within six months after transplantation

Tacrolimus doubles risk of new diabetes mellitus requiring insulin compared with ciclosporin

Graft survival is maximised and risk of diabetes minimised when tacrolimus target concentrations are $<10 \mathrm{ng} / \mathrm{ml}$ over the first year after transplantation. responses in renal transplant recipients: 4-month follow-up of a prospective randomized study. Transplant Proc 2002;34:2377-8.

39 White SA, Bicknell GR, Jain S, Williams ST, Doughman T, Furness P, et al. Effect of acute rejection on expression of fibrosis associated genes in renal transplant recipients. Transplant Proc 2000;32:19-20.

40 Yang HC, Holman MJ, Langhoff E, Ulsh PJ, Dellock CA, Gupta M, et al Tacrolimus/"low-dose" mycophenolate mofetil versus microemulsion cyclosporine/ "low-dose" mycophenolate mofetil after kidney transplantation-1-year follow-up of a "low-dose" mycophenolate mofetil after kidney transplantation-1-year
prospective, randomized clinical trial. Transplant Proc 1999;31:1121-4.

prospective, randomized clinical trial. Transplant Proc 1999;31:1121-4.
41 Yu L, Wang Y, Fu SJ, Cheng XJ. Clinical experience with Prograf (tacrolimus, FK 506) in Chinese patients after renal transplantation. Transplant Proc 2000;32:1709-10.

42 Cecka JM, Gjertson DW, Terasaki PI. Pediatric renal transplantation: a review of the UNOS data. Pediatr Transplant 1997;1:55-64.

43 Ojo AO, Port FK, Held PJ, Wolfe RA, Turenne MN, Chung E, et al. Inferior outcome of two-haplotype matched renal transplants in blacks: role of early rejection. Kidney Int 1995; $48: 1592-9$

44 Egger M. Problems and limitations in conducting systematic reviews. In: Egger M, ed. Systematic reviews in health care. 2nd ed. London: BMJ books, 2001:43-68.

45 Cuervo LG, Clarke M. Balancing benefits and harms in health care. BMJ 2003;327:65-6.

46 Tunis SR, Styer DB, Clancy CM. Practical clinical trials: increasing the value of clinical research for decision making in clinical and health policy. JAMA 2003;290:1624-32.

47 Hariharan S, McBride MA, Cohen EP. Evolution of endpoints for renal transplant outcome. Am J Transplant 2003;3:933-41.

48 Lachenbruch PA, Rosenberg AS, Bonvini E, CavaillA. Biomarkers and surrogate endpoints in renal transplantation: present status and considerations for clinical trial design. Am J Transplant 2004;4:451-7.

49 Thompson SG, Higgins JP. How should meta-regression analyses be undertaken and interpreted? Stat Med 2002;21:1559-73.

50 De Mattos AM, Olyaei AJ, Bennett WM. Nephrotoxicity of immunosuppressive drugs: long-term consequences and challenges for the future. Am J Kidney Dis 2000;35:333-46.

51 Gourishankar S, Halloran PF. Late deterioration of organ transplants: a problem in injury and homeostasis. Curr Opin Immunol 2002;14:576-83.

52 Nankivell BJ, Borrows RJ, Fung CL, O'Connell PJ, Allen RD, Chapman JR. The natural history of chronic allograft nephropathy. N Engl J Med 2003;349:2326-33.

53 Nankivell BJ, Borrows RJ, Fung CL, O'Connell PJ, Chapman JR, Allen RD. Calcineurin inhibitor nephrotoxicity: longitudinal assessment by protocol histology. Transplantation 2004;78:557-65.

54 Berlin JA, Santanna J, Schmid CH, Szczech LA, Feldman HI, Anti-Lymphocyte Antibody Induction Therapy Study Group. Individual patient- versus group-level data meta-regressions for the investigation of treatment effect modifiers: ecological bias rears its ugly head. Stat Med 2002;21:371-87.

55 Knoll GA, Bell RC. Tacrolimus versus cyclosporin for immunosuppression in renal transplantation: meta-analysis of randomised trials. BMJ 1999;318:1104-7.

56 Heisel OH. New onset diabetes mellitus in patients receiving calcineurin inhibitors: a systematic review and meta-analysis. Am J Transplant 2004;4:583-95.

57 National Institute for Clinical Excellence. Immunosuppressive therapy for renal transplantation in adults. London: NICE, 2004. (Technology appraisal 85.)

(Accepted 1 August 2005)

doi $10.1136 /$ bmj.38569.471007.AE

Cochrane Renal Group, Centre for Kidney Research, Children's Hospital at Westmead, Westmead, NSW 2145, Australia

Angela C Webster research fellow

Centre for Transplant and Renal Research, Department of Renal Medicine, Westmead Hospital, Westmead

Jeremy R Chapman clinical professor

School of Public Health, University of Sydney, Sydney, NSW 2006, Australia Jonathan C Craig associate professor (clinical epidemiology)

Department of Public Health and Epidemiology, University of Birmingham, Birmingham B15 2TT

Rebecca C Woodroffe systematic reviewer

Rod S Taylor senior lecturer

Correspondence to: A C Webster angelaw2@chw.edu.au or angela.webster@gmail.com 